\title{
The Moral Wrestler: Ignored by Maslow
}

\section{Foundations}

\author{
Amitai Etzioni ${ }^{1}$
}

Published online: 18 October 2017

(C) Springer Science+Business Media, LLC 2017

One of Maslow's great contributions is that he assumes that people are not merely economic creators who seek to maximize their happiness by consuming goods. He holds that once people's basic needs are satisfied, they will find contentment in seeking to address "higher" needs-famously esteem and self-actualization. However, Maslow's theory is still completely self-centered. The esteem a person seeks is for his or her own psychological well-being. And selfactualization is - for the self.

To view people as moral creatures, social sciences need to draw much more on a traditional view of human nature, found in the three Abrahamic religions. It views human beings as morally flawed. People are able to tell right from wrong, but they keep straying. They are assumed - by their very nature - to engage in a life-long wrestle between the better angels of their nature and their debased self. So far, much of social sciences sought to explain human behavior in empirical, secular terms. Each social science had its own conception of human nature; indeed, each had several and changing views of what makes people tick and relate to one another. Some lost sight of the moral wrestling, while others came to the rescue, but in the process opened a Pandora's box.

\section{Homo Economicus: The Leading Culprit}

Economics is considered by academics as the queen of the social sciences, the most prestigious of the lot. It carries more

\section{Amitai Etzioni}

etzioni@gwu.edu

1 The George Washington University, Washington, DC 20037, USA weight in the public and private spheres than all the other social sciences combined. It is not an accident that the White House has a Council of Economic Advisers, but all suggestions to create a Council of Social Advisers have been rebuffed. Of the 19 public policy schools in the US, at least 18 are dominated by economists. In the private sector, MBAs lord over other social scientists, who are most often relegated to "HR," the human resources division, as second class citizens.

Mainstream economics was based on a meta-conception of human nature, often referred to as homo economicus. People were assumed to seek to maximize their self-interest, which was equated with satisfaction drawn from the consumption of goods. In short, as seeking material hedonism. This thesis is often expressed by the use of the term "utility." The original concept of utility, as developed late in the eighteenth century by Jeremy Bentham, is narrow: All actions are directed toward gaining pleasure or avoiding pain. ${ }^{1}$ Happiness, satisfaction, and pleasure are treated as synonyms. ${ }^{2}$ Utilitarian philosophy views pain and pleasure not only as sources of motivation, but also of ethical guides: "It is for them [pain and pleasure] alone to point out what we ought to do" and determine the "standard of right and wrong."3 Along similar lines, John Stuart Mill wrote that "actions are right in proportion as they tend to

\footnotetext{
${ }_{1}^{1}$ Jeremy Bentham, An Introduction to the Principles of Morals and Legislation (Oxford: Clarendon Press, 1789), accessed June 92015 at http:// caae.phil.cmu.edu/ ("By utility is meant that property in any object, whereby it tends to produce benefit, advantage, pleasure, good, or happiness, (all this in the present case comes to the same thing); or (what comes again to the same thing) to prevent the happening of mischief, pain, evil, or unhappiness to the party whose interest is considered.").

${ }^{2}$ See for example Fred Gottheil, Principles of Economics 7ed, (Boston: Cengage Learning, 2013) 121.

3 Jeremy Bentham, An Introduction to the Principles of Morals and Legislation (Oxford: Clarendon Press, 1789), accessed June 92015 at http:// caae.phil.cmu.edu.
} 
promote happiness; wrong as they tend to produce the reverse of happiness," with happiness defined as "pleasure and the absence of pain." ${ }^{4}$ When British philosopher Thomas Hobbes was asked why he gave a coin to a beggar, Hobbes replied that "he made his donation with the sole intent of relieving his own misery at the sight of the beggar." ${ }^{5}$ Adam Smith famously argued in The Wealth of Nations that the market as a system relies on each actor pursuing his self-interest:

It is not from the benevolence of the butcher, the brewer or the baker that we expect our dinner, but from their regard to their own interest. We address ourselves not to their humanity but to their self-love, and never talk to them of our own necessities but of their advantages. ${ }^{6}$

The hedonistic version of utilitarianism forms the foundation of modern economic theory. ${ }^{7}$ Economists often associated utility with conceptions of material goods and, hence, with income. For example, Libby Rittenberg and Timothy Tregarthen define utility as the "satisfaction" that "people derive from the goods and services they consume and the activities they pursue."

Economists argue that they have moved away from this definition of utility. Some hold that it is being replaced with the notion that utility is whatever the person prefers; it does not require a particular content. Thus, Gary Becker's approach rebutted earlier economists" "assumptions of self-interest"; he replaced them with the idea that "individuals maximize [their own] welfare, as they conceive it, whether they be selfish, altruistic, loyal, spiteful, or masochistic." ${ }^{9}$ However, in effect, many economists (and other social scientists who hold similar assumptions) continue to rely on utility as happiness And on happiness as derived mainly from material goods.

These social scientists have gone to great lengths to defend their view of what drives people. Gift-giving, for example, seems to contradict hedonism because it involves a voluntary reduction of one's own utility, in order to benefit that of others. Economists have responded by arguing that gift-giving is often driven by "cooperative egoism," with those who give gifts expecting reciprocal gifts, reputation, status, approval, or some future benefit. ${ }^{10}$ And to the extent that gift-giving occurs

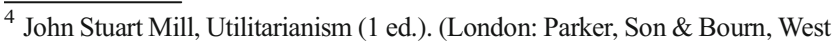
Strand, 1863) Accessed June 92015 at www.utilitarianism.com/.

${ }^{5}$ John Aubrey, Brief Lives, Clark,A . (ed.), (Oxford: Clarendon Press 1898): 352.

${ }^{6}$ Adam Smith, The Wealth of Nations, Modern Library Edition (1776, reprint, New York: Random House, 1937) 14.

${ }^{7}$ George Stigler, The Theory of Price (New York: Macmillan Publishing Company, 1987): 52.

${ }^{8}$ Greg Mankiw Principles of Microeconomics 6ed (Boston: Cengage Learning, 2011): 285.

9 Justin Wolfers, "How Gary Becker Transformed the Social Sciences," The New York Times, May 5, 2014, Available at http://www.nytimes.com/.

${ }^{10}$ See for example Peter Hammond, "Charity: Altruism or Cooperative Egoism?" In Altruism, Morality, and Economic Theory, edited by Edmund S. Phelps. (New York: Sage Found., 1975).
}

in the absence of such expected rewards, for example in the case of anonymous gift-giving, economists argue that the giver enjoys a "warm glow" from the act of gift-giving itself. ${ }^{11}$

Likewise, given the fact that participation in religious activities cannot be explained merely by an "expected stream of 'benefits" over an individual's lifetime, Corry Azzi and Ronald Ehrenberg introduced the ideas of a "salvation motive" to secure "afterlife consumption." 12 Put simply, they claim, individuals spend money and time on religion in this life with the expectation that they will be rewarded handsomely after death. Needless to say, there is very little evidence to support this proposition.

To dismiss the role of moral values in decision making, economists have gone to great lengths to explain "surprising" behavior. One example is the prevalence of tipping at restaurants. Tipping does not make sense to economists, particularly data that reveals that people tip about the same amount regardless of whether they intend to return to the restaurant in the future, ${ }^{13}$ i.e. those who tip cannot expect to get anything in return. Tipping is hence regarded as "mysterious or seemingly irrational behavior." ${ }^{14}$ Similar arguments have proposed a "bequest motive" to explain "excessive" saving, ${ }^{15}$ as well as a "taste for altruism" on the part of employees of not-for-profit enterprises, who are said to "derive well-being from participating in the enterprise, and are thus willing to accept a lower wage." 16

Under withering criticism, economists adapted their conception of human behavior some. Many agreed that people may have other motives than self-interest when dealing with the members of their immediate family (in economists' speak, "household") and hence decided that the "self" homo economicus is out to serve includes one's children and spouse. Others tried debunking other-directed or altruistic behavior as merely camouflaging forms of egotism (e.g. seeking prestige).

Most recently, economists moved to argue that it does not matter what one seeks, as long as one's preferences are served. Thus, moral behavior is treated as one's "taste" which disappears in the wash because it is dumped in with all the other

\footnotetext{
${ }^{11}$ See for example James Andreoni, "Impure Altruism and Donations to Public Goods: A Theory of Warm-Glow Giving," The Economic Journal, 100:401 (1990) 464-477.

${ }^{12}$ Corry Azzi and Ronald Ehrenberg, "Household allocation of time and church attendance," Journal of Political Economy 83:1 (1975): 27-56.

${ }^{13}$ Daniel Kahneman, Jack L. Knetsch, and Richard H. Thaler, "Fairness as a Constraint on Profit Seeking: Entitlements in the Market," The American Economic Review, 76:4 (1986) 728-741.

${ }^{14}$ Michael Lynn, "Tipping in restaurants and around the globe: An interdisciplinary review," Cornell University, SHA (2006), accessed June 262015 at http://scholarship.sha.cornell.edu.

${ }^{15}$ Hendrik Jurges, "Do Germans Save to Leave an Estate? An Examination of the Bequest Motive," The Scandinavian Journal of Economics 103:3 (2001) 391-414.

${ }^{16}$ Jasmine McGinnis, "The Young and the Restless: Generation Y in the Nonprofit Workforce," Public Administration Quarterly, 35:3 (2011): 342362.
} 
preferences. There is no difference, even according to this updated economists' conception of human nature, between volunteering and watching TV, making a donation and removing cash from the passing plate, fighting for one's nation, and avoiding the draft. Moral wrestling is for the birds.

Economists did not develop a conception of a good society; many economists would rather jump off the Golden Gate Bridge than use such a morally loaded term in their academic works. Instead they refer to the social welfare of people. Economies are considered to provide more welfare the more wealth the economy produces is distributed in ways that satisfy more of the preferences of more people. It is the greatest happiness of the greatest number, all over again. The trouble with this conception - which avoids judgment, most importantly of whether any given distribution of economic assets is just-is that it takes for granted that the preferences of people reflect their true will and self. However, once one notes that preferences are affected by advertising and other forms of manipulation, one realizes that any given distribution of wealth needs to be morally assessed. If the distribution of wealth truly reflected the freely expressed values and wishes of people - and one would judge this distribution as unfair or damaging to the common good, or otherwise morally flawed - one would have to argue with people about the choices they made. That is, to try to convince them to make moral choices. However, if people's wishes are "doctored," are manipulated, one's main beef is with those who manipulate them and much less with the victims of manipulation. This is clearly the most common condition.

To provide but one example: over recent years the waxing industries have convinced women that it is very uncouth to have any hair in their private parts. Since then, large segments of young women pay good money to have these hairs removed. (Most recently the same industries set out to convince men to act in the same way). If one considers these kinds of expenditures as previously compared to say buying a book or helping those in need, one's first quarrel is with the industry, and only then with those who should know better than heed the siren calls of the marketers.

Aside from a profound misunderstanding of moral wrestling, economics has a side effect: data show that those who are swayed by it act less morally then others. This was demonstrated when two social scientists organized a game that allowed people to free ride, that is benefit from the group's efforts without doing their share of the work. Twelve groups participated in the game. In eleven most participants did rather little free riding; in the twelfth group most everyone did. Turns out, it was full of graduate students in economics.

\section{Homo Sapiens as Clueless}

Over the last decades, a major branch of psychology, referred to as behavioral economics, set out to prove economists wrong and proffer a rather different conception of human nature. Several of these psychologists use the term Econs for homo economicus, and Humans for Homo sapiens. Their findings and their implications have been summarized in a best-selling book, Thinking, Fast and Slow by the Nobel Laureate psychologist Daniel Kahneman.

The main finding of behavioral economics, supported by robust evidence from both experiments and field studies, is that people have hardwired, innate, cognitive biases. These lead them to systematically misperceive facts and draw wrong conclusions from them. Because they fear loss more than losing a gain, they see a $\$ 1000$ salary cut as a much bigger deal than not getting a $\$ 1000$ raise. They view spending $\$ 100$ as a major outlay if they just spend $\$ 20$ on something else, but not if their last purchase cost $\$ 300$. They do not get around to putting money into a retirement account, even when often reminded, and even if there are strong economic advantages to doing so. And they still are fooled by marketers who charge \$3.99 for an item, which people see as costing \$3 rather than 4. And so on and so on. Moreover, even people with high IQs, after being trained in statistics, do not function significantly better. That is, their intellectual defects are so strong, education and training cannot do much to remedy these innate, hardwired intellectual flaws.

Richard Thaler is another towering behavioral economist. He served as the President of the American Economic Association and was awarded the Nobel Prize in economics in 2017. He wrote a book which he entitled Misbehaving. One may think that we finally have a behavioral economist who makes deviating from what is considered moral behavior his topic. Far from it. For Thaler, "misbehaving" is an ironic term. It happens when people behave - as we all do all the time - in ways that conflict with the ways economics assume people will behave. We "misbehave" when we act on the basis of poorly collected, poorly analyzed, misunderstood information, from which we draw the wrong conclusions - far from the rational way economics assumes people will act. We stumble through life like a drunken sailor.

Behavioral economics as a school has not applied its findings to improve our understanding of moral wrestling. It has its hands full, it seems, trying to convince mainstream economics of the need to adapt its models to the fact that people are, to put it succinctly, not rational creatures. In short, behavioral economics finds that we are clueless but has precious little to say about the ebbs and flows of moral wrestling, above all about what makes us better than we would be otherwise.

\section{Be Happy}

A small school of social scientists, drawn from a variety of disciplines, studies what makes people happy. The focus of these studies reveals the reluctance of social scientists to view 
moral commitments and living up to them - as a source of a profound sense of contentment.

A very elementary measurement widely used to study happiness is to simply ask people whether they are happy. For example, an annual study of Europeans asks: "Taking all things together, how would you say things are these dayswould you say you're very happy, fairly happy, or not too happy these days?"17 A similar study asks: "Taken all together, how would you say things are these days - would you say that you are very happy, pretty happy, or not too happy?"18 Indeed, much of the literature on happiness relies on such selfreporting of happiness, ${ }^{19}$ as do reports by the prestigious Pew Research Center on parenthood and happiness. ${ }^{20}$

Aside from assessing the state of individuals, measurements such as gross national happiness $(\mathrm{GNH})$ have been introduced to assess various social groups and whole societies. Common to many of these studies is an underlying philosophy of classical hedonistic utilitarianism, which holds that societies ought to maximize "the sum-total of happiness." ${ }^{21}$ These measurements are hence based on the number of individuals who state that they are happy, rather than how good they areby any definition of good. ${ }^{22}$ Nor do they take into account whether being moral affects one's happiness, and if it does not - what considerations should prevail and when? That is, if a desire for happiness does not encourage moral conduct, and in fact undermines it, should we continue to give such a high premium to what makes people happy? Maybe some suffering and sacrifices are better than disco dancing, the best roll in the hay, and a feast kings would cheer?

Questions about happiness (e.g., "Did you smile today?") have been criticized on the grounds that they are like snapshots that capture a person's feelings at a single point in time. Hence, several social scientists turned to ask people questions about "life satisfaction." For example, an often-cited study of life satisfaction is the OECD Better Life Index, which asks people to "evaluate their life as a whole rather than their

\footnotetext{
${ }^{17}$ Rafael Di Tella, Robert J. McCulloch, and Andrew J. Oswald, "The Macroeconomics of Happiness," The Review of Economics and Statistics 85(4), 2003, 810-811.

18 “General Social Survey," Accessed June 1, 2015, Available at http://www3. norc.org/GSS+Website/.

Bruno S. Frey and Alois Stutzer, "What can economists learn from happiness research?" Journal of Economic Literature 40(2), 2002, 405.

Rafael Di Tella, Robert J. McCulloch, and Andrew J. Oswald, "The Macroeconomics of Happiness," The Review of Economics and Statistics 85(4), 2003, 810-811.

19 Dimitrios Xefteris, "Formalizing Happiness," Journal of Happiness Studies 13(2), 2012, 291.

${ }^{20}$ Kim Parker, "Parenthood and happiness: It's more complicated than you think," Pew Research Center, February 7, 2014, Available at http://www. pewresearch.org/fact-tank/2014/02/07/parenthood-and-happiness-its-morecomplicated-than-you-think/.

${ }^{21}$ Torbjörn Tännsjö, "Narrow Hedonism," Journal of Happiness Studies 8(1), $2007,81$.

22 Rafael Di Tella and Robert MacCulloch, "Some Uses of Happiness Data in Economics," The Journal of Economic Perspectives 20(1), 2006, 26.
}

current feelings." Such wording of the questions respondents are asked may indeed be superior to "did you smile today," but does not get us any closer to studying moral wrestling.

Most recently, happiness studies sought to broaden their scope by focusing on the question of whether people feel that their life has "meaning." Having a meaningful life is considered, well, more meaningful, than just being happy. However, this concern is also morally neutral, if not morally neutered. Gang members and Jihadists feel that their lives are as meaningful or more than those who work in most factories and offices, or retire to play golf or dominoes.

\section{It Is All in Our Genes}

James Q. Wilson, a renowned political scientist, believed that people have an innate sense of fairness. Studies show that very young toddlers have a sense of empathy. Evolutionary biologists hold that people are sympathetic to others because this moral predisposition was an advantage in the early days when people had to share the spoils of what they hunted and were safer as a group. Those who were not sympathetic got less food and security, and hence-they and their genes - were less likely to survive. A review of the sociobiological argument that people have an altruistic gene will serve to examine all such claims.

This argument can be advanced basically in one of two forms. In one, the gene determines the moral positions of the actor, i.e. moral people are born, not fashioned. However, one cannot but wonder, given the rapid changes in the extent to which people are altruistic, how these changes could be accounted for by genes that are set for one's lifetime. For instance, initially, when the German Chancellor welcomed a million refugees, her policy was very widely supported by the German people. However, following a few incidents - sexual assaults during an Oktoberfest, a machete attack - the German people turned out to be much less sympathetic to the same refugees (and to their Chancellor). Such changes, which are very common, are incompatible with the notion that people have genes that make them moral in one way or another. If, on the other hand, one considers genes merely as predispositions - then all the key questions about moral wrestling remain unanswered. What are the factors that make people heed their genetic predisposition versus disregard it? Nurture it or fight it? In short, it does not seem that we will find in the genes a scientific basis for or an understanding of what causes improvements or losses in the outcome of the wrestling.

Other socio-biologists argued that altruism improves your chance in the process of natural selection. This is said to be the case because if you extend help to others - they will help you in times of need. Hence, over time those with altruistic predispositions are more likely to survive. It is far from clear how genes - or natural selection - will ensure say that children will take care of the old and infirm parents who once invested 
enormous time, sleep, and money to raise them - some sixty years earlier. Anyhow, if altruism is understood is merely an exchange of services, a mutual or intergeneration deal, we are not dealing with moral wrestling.

The softer social sciences - anthropology, sociology, and psychology - did better in providing secular and empirical understanding of moral wresting. In the process, though, we shall see, they opened a Pandora's box.

\section{Anthropology Liberates-But Engenders Cultural Relativism}

Ruth Benedict had and has a major effect on the conception of human nature. Benedict in Patterns of Culture described the values of the Kwakiutl of the Pacific Northwest, the Pueblo of New Mexico, and the Dobu culture of New Guinea, and in a later work that of the Japanese. She stressed that although to Western eyes the moral values of these very different societies (or tribes) may seem strange if not objectionable, each made sense once they were understood within the context of the moral culture of the various societies.

Viewed in the context in which her works and those of other leading anthropologists (especially Franz Boas and Margaret Mead) were published at the time - in the mid twentieth century - they served a major antidote to cultural imperialism, to the arrogant but widely-held notion among colonizing nations that they were called upon to bring light to the primitives. At the same time, by arguing that the values of the different cultures were merely different, rather than some being morally superior to others, she and her colleagues in effect promoted moral relativism.

True, some social scientists tried to save the day by maintaining that these anthropological positions amounted merely to 'methodological relativism,' the need for unbiased studying of cultures different than those of the social scientist who did the study. However, their findings were often cited and commonly used to support philosophical relativism, the real thing, the suspension of moral judgment which takes the oomph out of moral wrestling. Once one takes the position that I believe say in monogamy but you believe in polygamy, and I have no basis on which to tell you that my choice is more moral than yours - we pull the rug out from under all cross-cultural moral claims. And because the same is true for subcultures within our society, we also leave these intra-societal judgments without a firm foundation.

Seeking an out, various social scientists argued that some values are held by all cultures, and hence could serve as a solid foundation for moral judgments. However, it turns out that even the most elementary moral value, thou shalt not kill, is not universally shared. Of course many cultures approve killing outsiders - whether they are Nazis, Communists, or infidels. However, many cultures also strongly lionize killing some of their own, for instance in so-called honor killings, in which fathers and brothers kill their daughters or sisters if they bring shame on the family. No exit here.

\section{Sociology: Collectivizing the Wrestle}

A major sociological insight is that what makes people more or less moral human beings, how well they wrestle, is The System: the power structure, the economy, and the culture. People abuse drugs, commit crimes, and walk out on their children mainly not because of their "bad character" but because they have been economically deprived, socially disadvantaged, politically disempowered, or otherwise alienated. The main moral wrestling does not take place within the person but within society. For instance, social movements - such as the women's rights, civil rights, and gay rights movements - made American society a less immoral place. Banks, deregulated, which sold subprime mortgages to millions of people and evicted them when they could not pay, and resisted reforms that were supposed to protect future millions from a similar fate, are not so much the work of "bad" people, but of a flawed system. The moral wrestler does not need better character education but political reforms, driven by societal changes in the distribution of power and assets, and parallel changes in the values fostered by the collective culture.

Sociologists (and social psychologists) added, on the personal level, the study of "socialization," the process through which newborn children are turned from animals into social creatures. This is achieved as the newborns bond with their caregivers (usually parents), who in turn draw on these bonds to implant moral values in those in their care. When these children grow older, they are exposed to other sources of values - in school, on TV and in social media, through peer pressure, and in places of worship. In the process these growing children slowly develop their own value profile These, in turn, are reinforced by what sociologists call "informal social controls," the approval and disapproval of others with whom people have meaningful social bonds, mainly their extended families, friends, and other community members.

One may wonder what all this has to do with moral wrestling? Sociology finds that children are just as likely to be "socialized" into a Nazi culture as into a liberal one, into the values of a KKK community as into a Hispanic one. Nowhere is the basic moral neutrality of this core sociological conception of human nature more in evidence than in the way sociologists treated the concept of being a deviant. In traditional cultures, people whose conduct differed from the one prescribed by the prevailing social values were labeled deviants. Lumped together were gay people, political dissidents, mental patients, and women who smoked or worked outside the home 
and criminals. They were all stigmatized and subjected to various correctional efforts and punishment.

Sociologists argue that these people were merely committed to a different set of values. Albert Cohen captured the widely held sociological position in these terms: "It is commonplace that normative rules vary enormously from one social system to another. It follows that no behavior is deviant in itself but only insofar as it violates the norms of some social system." Here sociology has made a major contribution to the liberal moral culture, to tolerance; it informs people that one who is considered deviant is actually just different. And - that one who was considered deviant yesterday will not be viewed so today or tomorrow. Look at gay marriages. In other words, sociology does embrace moral relativism not only on the societal but also on the personal level. It follows that some people may be more conformist than others but it does not make them better people, morally speaking. You can make people conform more but this does not make them better moral wrestlers, more able to figure out what is right and more able to live up to one's moral obligations.

\section{Clinical Psychology: From Freud to Morally Neutral}

Like all great texts, the work of Sigmund Freud can be read in different ways. However, for the purposes at hand, one basic and often shared interpretation will suffice. Freud, in effect, incorporated in a secular conception the age-old, religious conception of a moral wrestler. Accordingly people are struggling between the pulls of their debased self (the id) and the commands of the moral voice (the super ego). Sometimes, and under some conditions, one side prevails, and sometimes the other. Moreover, people construct out of these give-and-takes their own personality (ego). And, while the urges of the id can be channeled into pro-social behavior (through sublimation), such conversion is never fully successful. The id gnaws, the moral wrestling is never ending. (Moreover, the sublimation exacts its own psychological costs, captured in Civilization and its Discontent).

Clinical psychology has a number of different schools and gurus, all of its own. By and large, though, they tend to help the person liberate him or herself from the moralistic demands of their society and follow his or her own star. Thus, Philip Cushman finds that clinical therapeutics see the ideal individual as one who has gained a "masterful self", who can "function in a highly autonomous, isolated way," and is "self-sufficient." That is, free from the restraints moral demands society puts on people's desires. Therapy liberates people from the demons of their past, but leaving them free to follow whatever they lust for, without moral guidance.

Jerome Frank sees psychotherapies as sharing a value system that accords "primacy to individual self-fulfillment," such as, "maximum self-awareness, unlimited access to one's own feelings, increased autonomy and creativity." While Frank recognizes the benefit of self-realization, he warns against modern psychotherapy's focus on promoting personal happiness as its main focus. Frank points out that the literature of psychotherapy accords little attention to other virtues and values such as "the redemptive power of suffering, acceptance of one's lot in life, adherence to tradition, self-restraint and moderation." There is much to be said for freeing people from their inner demons, reflecting the defective ways they were brought up. However, psychotherapy tends to exorcise at the same time the moral dictates promoted by society. Those do deserve critical examination and reform, but not leaving people in a moral vacuum, surely not if one tries to understand under what conditions we become better moral wrestlers.

Maslow identified five fundamental categories of needs. Ranked from most basic to highest-order, these are physiological needs, safety-security, love and belonging, esteem, and self-actualization. ${ }^{23}$ Self-actualization, considered the highest need, is defined as achieving the fullest use of one's talents and interests - the need "to become everything that one is capable of becoming." 24 As implied by its name, selfactualization is highly individualistic and reflects Maslow's premise that the self is "sovereign and inviolable" and entitled to "his or her own tastes, opinions, values, etc". ${ }^{25}$ That is, selfactualization refers to an individual need for fulfillment. ${ }^{26}$ The particular form self-actualization takes varies greatly from person to person. In some individuals "it may take the form of the desire to be an ideal mother, in another it may be expressed athletically, and in still another it may be expressed in painting pictures or in inventions." 27 Indeed, some have characterized self-actualization as "healthy narcissism." 28

\section{Social Psychology: Powerful Narratives}

Psychology is fragmented into fields that are as different from one another as poetry is from a car manual. Some psychologies are concerned with other matters than human nature, let alone moral wrestling. For example, comparative psychology focuses on animal behavior, in the expectation that studies on rats, dogs, or monkeys, for example, will yield valuable insights about

\footnotetext{
${ }^{23}$ David Lester, "Maslow's hierarchy of needs and personality," Personality and Individual Differences 11:11, (1990): 1187.

${ }^{24}$ Michael R. Hagerty, “Testing Maslow's Hierarchy of Needs: National Quality-of-Life Across Time," Social Indicators Research 46(xx), 1999, 250.

${ }^{25}$ Adrianne Aron, "Maslow's Other Child," Journal of Humanistic Psychology 17(2), 1977, 13.

${ }^{26}$ Michael R. Hagerty, “Testing Maslow's Hierarchy of Needs: National Quality-of-Life Across Time," Social Indicators Research 46(xx), 1999, 250.

${ }^{27}$ Mark E. Koltko-Rivera, "Recovering the Later Version of Maslow's Hierarchy of Needs: Self-Transcendence and Opportunities for Theory, Research, and Unification," Review of General Psychology 10(4), 2006, 303.

${ }^{28}$ Thierry Pauchant and Collette A. Dumas, "Abraham Maslow and Heinz Kohut: A Comparison,” Journal of Humanistic Psychology 31(2), 1991, 58.
} 
human behavior. Biological psychology and cognitive psychology are also otherwise occupied. Even abnormal psychology studies "mental, emotional and behavioral aberrations" but not moral ones. In a typical textbook, Introduction to Psychology by James W. Kalat, which runs 616 pages and provides an overview of the various schools of psychology - two pages deal with moral variables. And these deal with moral reasoning and not moral motivation and commitments.

Reference is to the various sub-disciplines, their dominant texts, concepts and most followers. Each of these psychologies though has individual scholars who made contributions to the study of moral wrestling, for instance Jonathan Haidt. Also, there is an important but small group of psychologists who study moral emotions, including Joshua Knobe, Stephen Darwall, Michael Lewis, and June Tangney. However, their work is not widely known and surely had not affected most of psychology as a review of even the most recent textbooks reveals.

Moreover, quite a few psychologists have adopted the selfcentered, self-satisfying, hedonistic perspective. Elliott Sober points out that it is "easy to invent egoistic explanations for even the most harrowing acts of self-sacrifice," for while such arguments may seem "forced," they are difficult to falsify without being able to read minds. For example, one "fixture" in the debate about egoism is the soldier who throws himself on a grenade to save his comrades - though seemingly a purely selfless act, psychological egoists argue that the soldier "realizes in an instant" that acting with cowardice would condemn him to a lifetime of guilt and shame that would be worse than death. ${ }^{29}$ In other words, the soldier acts in his own selfinterest to achieve "a better life, in terms of welfare" or utility. ${ }^{30}$ Some have even argued that suicide represents a utilitymaximizing behavior for an individual whose "total discounted lifetime utility [...] reaches zero." 31

A major contribution psychology had and is making to our understanding of moral wrestling are several very powerful narratives that grew out of experiments psychologists conducted. Although these are works of scientific research rather than ethical deliberations, they resulted in major narratives that are helping people in their moral wrestling, For example, during the 1960s, psychologist Stanley Milgram conducted an experiment on people's obedience to authority figures after he learned about Nazi war criminal Adolf Eichmann's defense in the Nuremberg trials that he was "just following orders." ${ }^{32}$ In

\footnotetext{
${ }^{29}$ Elliott Sober, "Psychological Egoism," in The Blackwell Guide to Ethical Theory, Ed. Hugh LaFollette Oxford: Blackwell (2000): 129-148.

${ }^{30}$ Robert Shaver, "Egoism" Stanford Encyclopedia of Philosophy, Dec 24, 2014, accessed June 232015 at http://stanford.library.usyd.edu.au/entries/ egoism/.

${ }^{31}$ Daniel S. Hamermesh and Neal M. Soss, "An Economic Theory of Suicide," Journal of Political Economy, .82:1 (1974):. 83-98; see also Gary Becker, "Suicide and its Assistance," The Becker Posner Blog, February 5 2012, accessed June 262015 at http://www.becker-posner-blog.com/.

32 Milgram, Stanley Behavioral Study of obedience. The Journal of Abnormal and Social Psychology, Vol 67(4), Oct 1963, 371-378.
}

the study, people were instructed to pull switches that they believed delivered painful shocks to other participants. Rather than the expected $3 \%$, a full $65 \%$ of participants delivered the maximum shock, a powerful indication of people's susceptibility to unethical leadership.

Philip Zimbardo carried out a prison experiment at Stanford which investigated the extent to which people's bad behavior can be attributed to their assigned social roles. ${ }^{33}$ In this study, participants were randomly assigned roles as guards or as inmates in a simulated prison. The "guards" quickly became aggressive and abusive, and the "inmates" began to develop emotional disorders so severe that the two-week study had to be ended after only six days. The findings created a powerful cautionary tale about people's tendency to conform to social expectations, whatever their moral content. Since then, the findings of these and other such psychological studies have been cited in numerous essays and classrooms about ethics; in sermons by ministers, priests and rabbis; and made into a movie. They are often used to warn people about the dangers of rising demagogues - and the need to be prepared to disobey orders that violate basic moral principles. Such narratives are a powerful tool of moral education. They make us into more effective moral wrestlers.

\section{In Conclusion}

Religion provides a conception of human nature and human fate, in which the struggle between good (moral) intentions and forces that worked to prevent them from being followed plays a key role. The Enlightenment led to a quest for a secular, evidence-based conception of human nature, and economics advanced a conception that has little room for moral wrestling. Behavioral economists' view of the person as intellectually limited seems all too valid, but the moral implications of these shortcomings remain to be spelled out. Social biology fashioned genetic explanations that treat moral behavior as either pre-determined or as needing explanation from other branches of social sciences. Anthropology made a major contribution when it liberated the moral wrestler from the association with white supremacy, but left him without a firm moral grounding. Sociology collectivized moral wrestling, a major contribution. Various psychologies avoid the subject, but some psychological studies do provide powerful insights into the moral nature of people and the struggle between their debased self and the nobler parts.

In short, some social sciences are blind to a critical element of human nature and of the good society. They add very little

\footnotetext{
${ }^{33}$ Haney, C., Banks, C., \& Zimbardo, P.G. (1973). Interpersonal dynamics in a simulated prison. International Journal of Criminology and Penology, 1, 6997.
} 
to the understanding of the forces that make individuals more vs. less moral. Indeed, some seem to unwittingly undermine the lifelong moral wrestling which is a defining characteristic of human nature. Other social sciences do improve our understanding of moral wresting - however, in the process they have undermined the very foundations of moral judgments. It seems that the place to look for new grounds on which to understand the forces that can make us better may be either in modern religions or in other forms of spirituality and transcendentalism, and in the works of those individual social scientists who do not conform to the norms of their disciplines.
Amitai Etzioni is a University Professor and professor of international relations at The George Washington University. In 1987 1989, he served as the Thomas Henry Carroll Ford Foundation Professor at the Harvard Business School. He served as Senior Advisor to the White House from 1979 to 1980 . He was guest scholar at the Brookings Institution in 1978-1979. For 20 years (1958-1978), he served as Professor of Sociology at Columbia University. Dr. Etzioni founded and was the first president (1989-90) of the International Society for the Advancement of Socio-Economics. He is the author of Among others, The Active Society and The Spirit of Community. 2100 Pennsylvania Ave., NW, Room 4058 